\title{
Handel's use of plucked instruments
}

\author{
Orlando Fraga (EMBAP)
}

\begin{abstract}
Three central features of Baroque music encompass a large portion of questions about the performance of this particular repertory: its improvisatory aspect, the use of basso continuo, and the instrumental color and variety. Teorbo and lute solos, aside of playing a role as a continuo, filled in the intermissions of oratorios in Italy since late 17th century, while organ concertos provided the same function for English oratorios in the early 18th century. It is from Handel's early period - his first trip to Italy in 1707 - that teorbo and archiliuto start to appear in his vocal music. Handel employed either the teorbo or archiliuto (or simply liuto) in twelve vocal works and in one instrumental Ouverture. A complete examination of the circumstances that involve this particular aspect of Handel's music is the subject this paper.
\end{abstract}

Keywords: Handel; Baroque opera; lute; theorbo; continuo.

Resumo: Um substancial número de questionamentos acerca da performance de música barroca se concentra em três aspectos particulares deste repertório: o seu aspecto improvisatório, o uso do baixo contínuo e a variedade e colorido da instrumentação. Solos de teorba e alaúde, além do seu papel como contínuo, preenchiam os intermezzos dos oratórios italianos desde o final do século 17, ao mesmo tempo em que concertos de órgão poderiam ter função equivalente nos oratórios ingleses no início do século 18. É no primeiro período composicional de Handel - aquele que coincide com sua primeira viajem à Itália em 1707 - que a teorba e o arquialaúde começam a aparecer em sua música vocal. Handel empregou tanto a teorba quanto o arquialaúde (ou simplesmente alaúde) em 12 trabalhos vocais, além de uma Overture instrumental. Este artigo examina as circunstâncias que envolvem os aspectos particulares deste repertório na obra de Handel.

Palavras-chave: Handel; Ópera Barroca; alaúde; teorba; contínuo. 
Despite Handel's fame as a composer, virtually no attention has been paid by scholars or performers to his use of plucked string instruments, especially those of the lute and guitar families. One of the possible reasons is that musicologists themselves rarely have in general any first-hand knowledge of plucked instruments. On the other hand, these instruments were considered to have been more or less extinct by the $18^{\text {th }}$ century. Nonetheless, my survey of entries in the Handel-Händbuch (HD) reveal at least fourteen pieces that call for lute, archlute, theorbo, or guitar. From this total, thirteen are vocal works - Oratorios, Operas, Cantatas, an Ode, an Anthem - plus one instrumental. Yet, three pieces call for an obbligato part, and the remaining mention the lute as part of the continuo contingent. These results raise some questions: how familiar was Handel with these instruments? Do these pieces work well on the specific instrument he designated? Did these instruments play along as part of the continuo when not specifically called for - in some other numbers in the same large-scale work?

I will begin this paper by introducing the characteristics of each instrument, assessing the feasibility of performing these pieces on each particular lute and the implications of playing an entire large-scale opera. By examining the scores, I will conclude that Handel did not have much knowledge of the lute. This is not unusual though, few composers ever do! However, he used it successfully to solve particular dramatic effects, and create a delicate, colorful musical fabric.

\section{The Instruments}

The nomenclature used by Handel is varied and sometimes confusing. This is actually to be expected from composers not completely acquainted with these instruments. To solve local incongruences, a composer would very often rely on the assistance of a lute performer. The final decision on which instrument to use and where would vary greatly according to the capabilities of the actual 
instrument and/or instrumentalist. Deviation from the original proposal could always be expected.

The theorbo (Fr. téorbe, théorbe, tuorbe; Germ. Theorb; It. Tiorba[o], tuorba) ${ }^{1}$ was first developed in Italy towards the end of the $16^{\text {th }}$ century. ${ }^{2}$ It was meant basically to accompany the Nuove Musiche of the Florentine Camerata. Because of its full, rich-sustaining sound, the theorbo was an excellent instrument to support a solo voice in monodic song without obscuring it. The Italian Tiorba came to England in the first decades of the $17^{\text {th }}$ century. Very soon, though, a new design was developed by the use two pegnuts for the bass courses. The solution was probably inspired by the English Two-Headed Lute, and is attributed to the English Gautier, Jacques. ${ }^{3}$ The term Theorbo-lute (or simply Theorbo) is often found on title-pages of collections of English Ayres. In examining this repertoire including consorts - we find a predominance of flat keys and slow pace of the bass line. Later in the century, the tessitura of the bass line tended to go higher and, therefore, the Renaissance G-tuning (also referred to as "lute pitch") with only the first course lowered by an octave (re-entrant tuning) ${ }^{4}$ proved to be ideal. Gut strings were standard although metal strings were often an alternative.

Whether used in chamber music, opera or church music, the theorbo gives a sonorous, full accompaniment, and for that reason it was thought a reasonable

\footnotetext{
${ }^{1}$ An instrument of the Western lute family with stopped courses considerably longer than those of a lute and with a separate nut and pegbox for a set of longer, unstopped bass strings (diapasons). The Italian names Chitarrone and tiorba were used synonymously for the same instrument, depending on personal or regional preferences. During the 17th century and part of the 18th the theorbo was popular as an accompanying instrument, and in the 17th century a certain amount of solo music in tablature was published for it. Theorbe may also refer to an organ reed stop of the 17th and 18th centuries German, rare but of a distinct type, i.e. gentle 16' tone imitating, in some way, the theorbo. In The New Grove Dictionary.

2 Mersenne (1637) says that it was invented in Florence 'thirty or fourty years ago' by le Bardella. In Mersenne, M. Seconde Partie de I'Harmonie Universalle: Livre septiesme des instruments. Paris, 1637, p. 77.

3 Jacques Gaultier (1603-1672).

${ }^{4} \mathrm{~A}$ term used to describe the tuning of string instruments in which successive strings are tuned not to successively higher pitches but to a pattern of rising and falling intervals. Reentrant tunings are found, for example, in the Renaissance four-course guitar $\left(g^{\prime} / g^{\prime}-d^{\prime} / d^{\prime}-\right.$ $\left.f^{\prime} / f^{\prime}-b^{\prime}\right)$, the Baroque five-course guitar $\left(a / a-d / d^{\prime}-g / g-b / b-e^{\prime} / e^{\prime}\right)$. Such tunings produce characteristic effects of timbre and colour, including bright chordal accompaniments and clarity of delineation in melodic passages. In The New Grove Dictionary.
} 
alternative to the violone. ${ }^{5}$ The theorbo read from the bass clef with harmonies added to the continuo part. Theorbos also were used as obbligato part. By the end of the $17^{\text {th }}$ century the archiliuto gradually replaced it, probably because the upper course of the archiliuto, being in lute pitch gave greater range for the bass, and allowed room for harmony and solos above that bass.

Fig. 1 The English Teorbo and its tunning

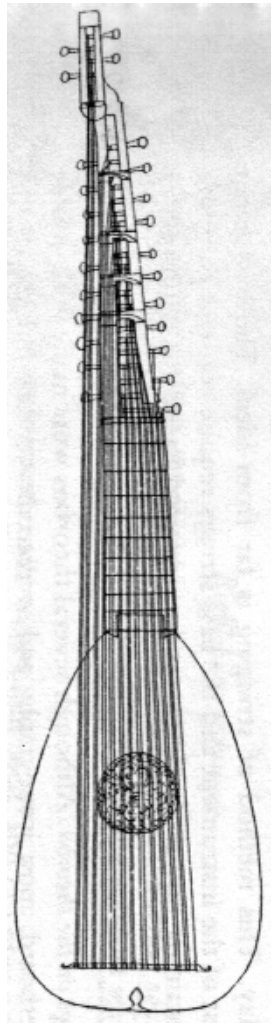

English Teorbo

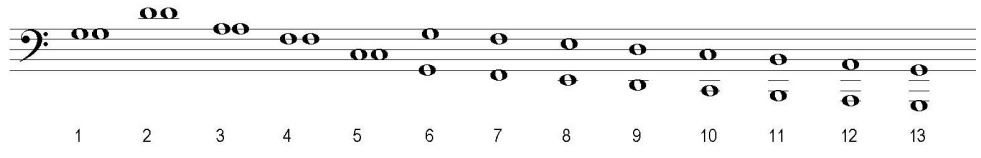

The Archiliuto (Fr. archiluth; Germ. Erzlaute; It. arciliuto, arcileuto) was a lute with six courses of stopped strings, and seven single or double courses of unstopped diapasons. The instrument was used principally for solo music, but was also called on to provide continuo.

\footnotetext{
${ }^{5}$ In 16th-century Italy violone was a generic term for the viol family. It distinguished the viol family from the violins, which in some early sources are called violette. By about 1600 violone had come to stand for a large bass viol. In The New Grove Dictionary.
} 
Alessandro Piccinini (1566 - c1638), in his Intavolatura di liuto, et di chitarrone (Bologna, 1623), claims the invention of this type of instrument in Padua in 1594 (Piccinini, 1623). He called it arciliuto because the name liuto attiorbado suggested that it was derived from the tiorbo which he knew to be untrue because he "invented it". The arciliuto started to appear in printed sources from the early $16^{\text {th }}$ century. Mersenne (1588 - 1648), in 1637, was allegedly confused between the terms tiorba and arciliuto. In his text he called the later tuorbe (sic), but in the errata he explained that the Italians called it arciliuto though he would have preferred luth à double manche (Mercenne, 1957). The old Renascence G-tuning remained unaltered in Italy throughout the $17^{\text {th }}$ - and $18^{\text {th }}$ centuries, while other European countries experimented with new tunings, culminating in the D-minor and Flat French tunings. ${ }^{6}$

However, the denomination of archiliuto did not gain universal acceptance until the last decades of the $17^{\text {th }}$ century. Two important new factors called for a more powerful continuo instrument. First, covered strings had been invented in the middle of the century, mentioned first time by J. Playford in 1664 (Playford, 1664). This kind of strings enabled a fuller sound to be produced on a shorter string. And second, the composers of the late $17^{\text {th }}$ century were writing richer and wide-ranging bass lines.

In Handel's time whenever liuto is specified for a continuo part it most likely means the arciliuto. This instrument is best used in instrumental music and anything that requires a more decorated realization. As composers began writing higher and more melodic bass lines toward the end of the $17^{\text {th }}$ century, the arciliuto proved to be more suitable than the English Teorbo. Like the teorbo, the arciliuto was also used as an obbligato instrument in chamber music, operas, and

\footnotetext{
${ }^{6}$ Around 1620 French lute composers began to experiment with several accords nouveaux (new tuning), first on ten-course lutes, and later on 11- and 12-course instruments. This experimentation continued until at least the 1670s, and music for over 20 different tunings survives, many of which were given different names by different scribes or composers. The tuning commonly known as 'Flat French' (A-d-g-b $\left.b^{b}-d^{\prime}-f^{\prime}\right)$ was popular until about the 1660s. The advantages of the new tunings were increased resonance and ease of left-hand fingering, though only within a very limited range of keys. In Lute - The New Grove Dictionary.
} 
cantatas. However, when it is used as a continuo instrument in late Baroque sonatas and cantatas, it is often necessary to add a bowed bass instrument.

It seems from the scores of Italian operas and oratorios that one performer was often expected to play both the arciliuto and teorbo using either one where appropriate. It would be expected that the player judge which instrument was best according the key and the nature of the bass. In general, the teorbo is best suited for sharp keys, recitatives, slow bass lines or those that do not go very high. The arciliuto is most suited for flat keys and aria accompaniment, obbligato or otherwise, with the bass line more active and of a higher tessitura.

Fig. 2 The arciliuto and its tunning

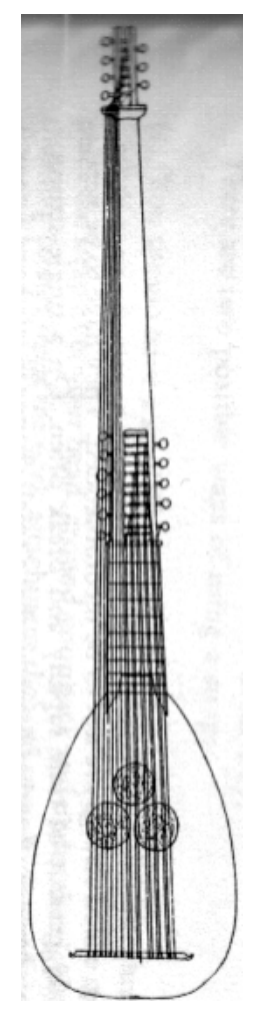

Arciliuto

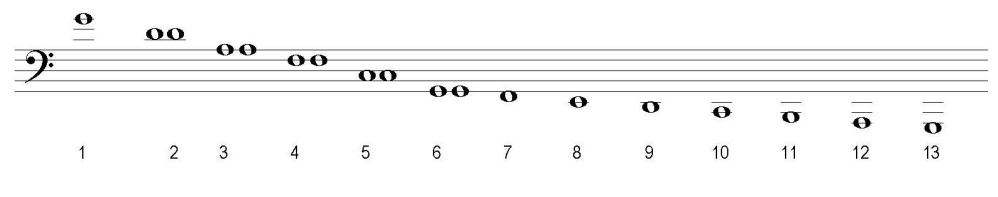

We should now consider the chitarra (or Baroque guitar) as a continuo instrument. Perhaps the most important function of the five-course chitarra in all periods of its existence has been as a chordal instrument, accompanying the voice 
and playing in ensemble. The earliest samples of guitar accompaniment are fully written out in tablature, alfabeto, ${ }^{7}$ and from late $17^{\text {th }}$ century on, also read from the bass part, wherein the guitar joined the harpsichord, lute, and teorbo, as part of the continuo contingent.

The style of accompaniment varied from strumming - particularly in dance music - to plucking, using the same technique as for solo guitar. Most significant for this study, is Nicola Matteis' publication Le false consonances della musica ... la chitarra sopra la parte, issued in Italy c.1680, and subsequently republished in England in 1682. In a most comprehensive way, Matteis deals with chords over the bass line, how to read figures, what to do with cadences, how to overcome the problems of rapid and difficult basses, and style of accompaniment. This book represented the foundation of continuo accompaniment for the following generations not only of guitarists, but also lutenists.

Fig 3 Baroque guitar and tuning

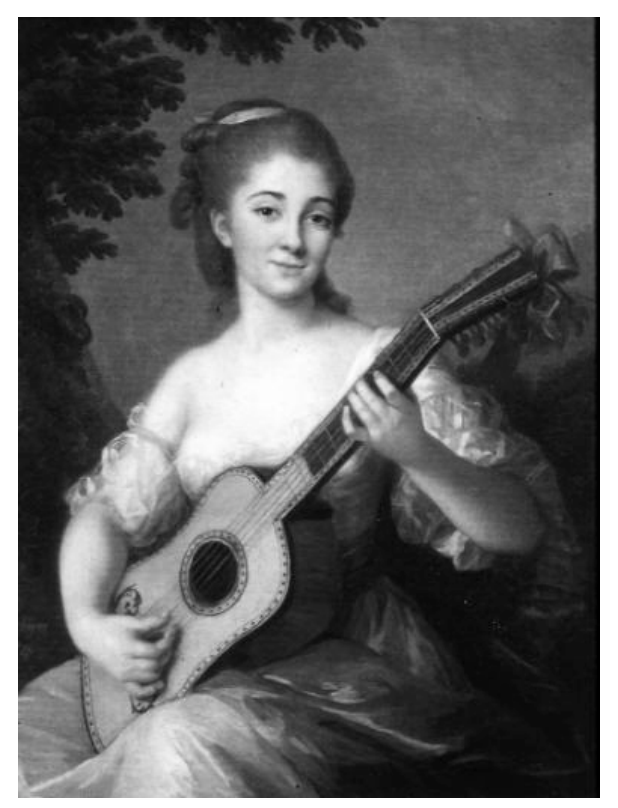

Chitarra

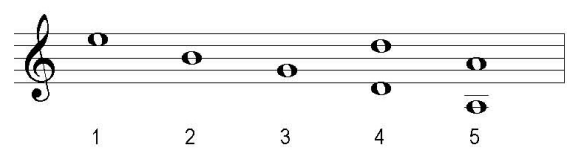

${ }^{7}$ Guitar notation in which chords are symbolized by letters of the alphabet and popular in early guitar sources, such as Carlo Calvi (1646), Gaspar Sanz (1674), Corbetta (1639), among others. In The New Grove Dictionary, Guitar. 
As a final word, it should be mentioned that whatever instrument one uses for continuo playing it is important to consider the special qualities of a particular type of lute or guitar, as well as the qualities of the repertoire. Yet, it should be understood that for almost two hundred years the term "theorbo" could refer to any one of the several large lutes, each one with a distinct feature. Its basic function was to play the continuo part and also often as a melodic and obbligato instrument. The tuning, stringing, range, design, and contour of the part play an important role in the final result.

\section{The Music}

The scores that constitute the basis for this study were drawn, according to the availability, from either the Händel-Handbuch (HG) or the Hallische HändelAusgabe (HHA). Of the total, three were not available by the time of the conclusion of the research. In any case, both the $H G$ and $H H A$ conflict to some extent, therefore an examination of the manuscripts was necessary.

Handel names four plucked instruments in his vocal and instrumental music: liuto, achiliuto, theorbo, and Baroque guitar. As we have seen above, the terms "liuto" and "archiliuto" were interchangeable; therefore they are here considered as one.

The designation 'archiliuto' appears in eight pieces:

Dramatic Cantata: Cornelia fedele, in vano speri (Clori, Tirsi e Fileno) (HWV 96) from 1707;

Oratorio: La Resurrezione (HWV 47) from 1708;

Ouverture D-Dur (HWV 337) from 1722;

Acis and Galatea (Italian/English version) (HWV 49b) from 1732;

Oratorio: Athalia (HWV 52) from 1733;

Wedding Anthem XIII: This is the day which the Lord hath made (HWV 262) from 1734;

Pasticcio Opera: Oreste (HWV A11) from 1734; 
Ode for St. Cecilia's Day (HWV 76) from 1739.

The works that call for theorbo are as follow:

Opera Seria: Giulio Cesare in Egitto (HWV 17) from 1724;

Opera Seria: Partenope (HWV 27) from 1730;

Opera Seria: Sosarme, re di Media (HWV 30) from1732;

Oratorio: Esther (HWV 50b) from 1732;

Oratorio: Saul (HWV 53) from 1739.

With the exception of the Overture in D Major HWV 337, all the pieces listed above belong to large vocal works. The first thing one wonders is to what extent Handel was aware of the problems of applying one or another instrument. It is fair to assume he would know at least the minimum of each instrument. But it is also fair to think that his main concern would not necessarily have been the small subtleties that particularize a lute. For the composer, the most basic concern is the final sound most suitable for the atmosphere he wants to suggest. In this regard, theorbo and archiliuto are very close to one another. That is to say, they possess the same characteristic color-tone distinguished only by specialists.

For an interpreter, the most basic thing to do in these situations is to evaluate the tessitura, the key, and the function of the part involved. At first glance we notice that five of the works that call for theorbo could actually not be played on this particular instrument for the simple reason that they do not possess the high $e^{3}$ present in the continuo line (a transposition an octave lower may be required). The exception would be the theorbo obbligato part in the Sinfonia that opens second act of Giulio Cesare. Although the range fits the tessitura of the theorbo, the key of $\mathrm{F}$ Major along with the arpeggio design would make it more suitable for an archiliuto. The dramatic situation also in the scene would suggest a bigger, louder instrument to cope with the volume of an onstage orchestra plus the regular one on the pit.

A special case involves La Ressurezione, here listed among the group of archiliuto but scored in Chrysander's edition for theorbo (and in the HandelHandbuch as archiliuto). In 1708, Handel was employed as a household musician 
to Marchese Francesco Maria di Ruspoli (primarily to compose cantatas for meetings of the Arcadian Academy) in Rome, where this oratorio was premiered on the $8^{\text {th }}$ of April. We can assume that an Italian instrument was used for this performance. For several reason I believe it was probably an archlute. The theorbo favored in Italy throughout the $17^{\text {th }}$ - and $18^{\text {th }}$-century has the first two courses reentrant. The range of the continuo part goes up to $d^{3}$, the higher open string, therefore leaving not too much room for a theorbo to fill in the harmony above the bass line. Furthermore, the key of $g$ minor, although possible on the theorbo, is definitely better for archiliuto.

The list of pieces for archiliuto is much less problematic. The aspects of range and key in Handel's music are congruent with the role of the instrument both as a continuo and obbligato part. Nevertheless, a particular case involving the oratorio Athalia and the anthem This is the Day should be considered. Athalia is one of the few oratories of Handel not originally composed for the London public. It was premiered in 10 July 1733 in the Sheldonian Theatre, Oxford. The Mathan's aria, Gentle airs for violoncello obbligato and continuo (double-bass, harpsichord, and archiliuto), which is in the key of A major, was reused a year later in the This is the day which the Lord hath made or Anthem for Wedding of Princess Anne (HWV 262). In the anthem, Handel changed the text (Blessed, Blessed is the man) and transposed the aria to G Major. Although both keys are feasible on the archiliuto, there is no doubt that $G$ Major, is better for its more robust resonance on the instrument due to the possibility of using more open strings. However, I do not believe Handel took these aspects of the instrument into account. Most likely the reason for the transposition lay in the change of cast from one performance to another.

For his continuo contingent, Handel suggests a variety of combinations. Along with the harpsichord, we find the viola da gamba, harp, violoncello, double-bass, and organ. Although the normal, and probably most desirable, interpretation of figured bass assumed the addition of chords (or some sort of contrapuntual filling of the score), it appears not to have been uncommon for arias and recitatives performed with the soloist to be accompanied only by a cello and/or other harmonic-melodic instrument such as the archiliuto or the theorbo. 
Metastasio, for instance, lamented about the early $18^{\text {th }}$ century cantatas that had no other accompaniment than "a harpsichord or a violoncello with no other instruments to obscure the beauties and hide the faults of the singing" (BROWN e SADIE, 1990, p. 122). The efficiency of the use of the theorbo and archiliuto as continuo may be determined by extra factors. First, the size of the hall. Whole genres of Baroque music - solo motets, secular vocal solos with guitar and lute accompaniment, suites for harpsichord, and etc. - were created for spaces that were either intimately small or had exceptionally good acoustics. Almost universally, theaters in the $18^{\text {th }}$ century were extremely small. For the audience, ground-floor seats were considered unattractive because the necks of large instruments, such as cellos and theorbos, blocked the view. The stage, on the other hand, in such theaters must have been extremely crowded, since they could accommodate six or more singers, small choruses, dance groups, and stage orchestras, when required. Thus, this leads to the second consideration: the size of the orchestras. Handel's oratorio La Ressurezione was performed with an orchestra of 48 musicians (BROWN e SADIE, p. 7). If we assume that the archiliuto was employed throughout the oratorio, then most likely the continuo section was reinforced with the addition of two or more archiliutos. Unfortunately, this information cannot be confirmed by consulting Ruspoli's account lists. ${ }^{8}$ In this case, Handel may have counted on the court lutenist with perhaps some extra hiring which does not appear for some reason in the accounts. ${ }^{9}$ On the other hand, from Handel's London period, we do know that it was a common practice of theaters and opera houses to have a lutenist as a permanent member. In 1728 , the account book of the Haymarket Opera lists an orchestra of 24 violins, 3 cellos, 2 double-basses, 3 bassoons, occasional flutes, trumpets, horns, 2 harpsichords, and an archiliuto. (BURROWS, 1985) Sir John Clerk, after attending the last night of Orlando (HWV 31) on May, 5 1733, listed a very similar orchestra in his diary:

\footnotetext{
${ }^{8}$ See Ursula Kirkendale.

9 The above mentioned article apparently lists only the entrances where Handel is mentioned. Handel may have used the house lutenist, if one ever existed, who does not appear in the accounts. That is a plausible assumption if we consider that at the same time Handel used viola da gamba, which is not mentioned anywhere in the accounts. Kirkendale, op. cit., p. 237.
} 
"above 24 violins, four cellos, 2 large bass violins each about 7 foot in length at least with strings proportionable that cou'd not be less than a $1 / 4$ of an inch diameter, two oboes, four bassons, a theorbo, and two harpsichord. The violins made a terrible noise \& often drown'd the voice" (Dean e Knapp, 1987). In any case, it is not unreasonable to assume that in the absence of a permanent member, players from elsewhere would be hired to fill the gap according to the availability of performers and immediate demand of budget. A third possibility is that Handel had a member of the vocal cast (or less likely, the orchestra) to play the lute. That is what Winton Dean implies in his article An unrecognized Handel singer: Carlo Arrigoni. The tenor Carlo Arrigoni was a skilled lute player also known for have taken part in some productions that involved Handel's permanent staff (Dean, 1977).

One question still remains: what would be the implications of a lute playing continuo throughout a large-scale work such as an opera? It is out of the range of this paper to consider whether or not the lute should play continuo where not specified. It was, however, a common practice, and the contemporary literature is rich in quotations. More important for us is how it was done; more specifically, the problems involving scordatura. For instance, if a given aria calls for an unstopped-bass course to be in $F$, and the next one is in $F \#$, it implies a retuning that demands that the player stand up and execute the actual awkward action. Obviously, that is not practical and may delay the flow of the opera. We may, therefore, assume that the lutenist would be prepared and backed-up with two or more instruments tuned differently. Yet, the second lute could be something else, for instance a theorbo - if the first one is an archiliuto - whenever the bass line and general affekt of the piece proves it to be more suitable

\section{Two Particular Cases}

\section{The cantata Nò se emenderá jamás (HWV 140)}

Handel's Italian cantatas (especially the single one with Spanish text and chitarra), were written for professional singers and instrumentalists who were as a 
rule employed as virtuosi in Rome chapels or courts. In other cases, the singers were members of the Capella Sistina or the Capella Giulia, and performed at the conversazioni of the Roman aristocracy with the permission of the Protettore of the Capella. From a total of nearly a hundred cantatas, Handel wrote four for solo voice and obbligato solo instrument and continuo: HWV 113 and 173 for violin, HWV 134 for the recorder, and HWV 140 for voice and Baroque guitar. To perform the guitar part, a five-course instrument in E-tuning is required. ${ }^{10}$ On examining the score, the first conclusion is that Handel most likely wrote it on a harpsichord and totally disregarded the instrument's range. In order to accommodate the bass line within the short tessitura of the guitar, the performer must transpose some notes an octave higher (actually, a common practice).

\section{Harp Concerto in B flat major or Organ Concerto in B flat major, Op 4 No 6 (HWV 294)}

Winton Dean owns a copy of the first edition of the libretto of Alexander's Feast from the performance at the Covent Garden in February and March of 1736. There, a single leaf stitched after the Preface of the Ode carries the complete text of the Cecilia volgi, headed A Cantata, perform'd at the Beginning of the Second Act. At three points in the Ode a concerto is indicated: the first one comes before the accompanied recitative The song began from Jove [A Concerto here, for the Harp, Lute, Lyricord, and other Instruments]. According to Dean, this agrees with directions in Handel's autograph (which does not contain the music of the concertos), although he originally placed an organ concerto before the accompanied recitative Thus long ago and shifted it to the end of the Ode. The first concerto is described as Concerto per il Liuto e I'Harpa. This Concerto was later published as Organ Concerto in B flat major, Op 4 No 6. Although this information is confirmed in the notes for this concerto in the Handel-Handbuch Vol. 3, p. 33, no further information was found that could shed more light on this.

\footnotetext{
10 Hans J. Marx in the Preface of his edition of the cantatas for the New Collection misattribute it. He suggests a guitar tuned in "A". That is actually not possible for the simple reason that there is no such a tuning. The Baroque guitar appears only in E-tuning.
} 
However, the sheer fact that this pieces most often referred to as Handel's "Harp Concerto" indicates how little Handel's use of the lute family is understood today.

\section{References}

BROWN, H. and SADIE, S. Performance Practice Music after 1600. London: W. W. Norton \& Co., 1990.

BURROWS, Donald. Handel's London theatre orchestra. Early music, United Kingdom. Vol. XIII/3 (August 1985), pp. 349-357.

BURROWS, Donald. Handel and the English Chapel Royal. London: Church Music Society, 1985.

DEAN, Winton. An unrecognised Handel singer: Carlo Arrigoni. Musical Times. Great Britain Vol. CXVIII/1613 (July 1977), pp. 556-58.

DEAN, W. and KNAPP, J. M. Handel's Operas - 1704-1726. Oxford: Clarendon Press, 1987.

GUDGER, William D. Handel's harp concerto. American Harp Journal. USA Vol. VI/3 (Summer 1978), pp. 14-22.

KIRKENDALE, Ursula. The Ruspoli Documents on Handel. Journal of the American Musicological Society. No. 25 (1967), pp. 235-270.

LEDBETTER, David. Continuo playing according to Handel. Oxford : Oxford University Press, 1990.

MATTEIS, Nicola. The false consonances of musick (1682). Complete facsimile edition with an introduction by James Tyler. Monaco: Editions Chanterelle, c1980.

MERSENNE, Marin. Harmonie universelle: the books on instruments. Translated by Roger E. Chapman. The Hague: M. Nijhoff, 1957.

PICCININI, Alessandro. Intavolatura di liuto, et di chitarrone. Bologna: 1623. Facsimile Minkkof, 1978.

PLAYFORD, J. A Brief Introduction to the Skill of Musik. London: 1664. Facsimile Minkkof, 1977.

ROGERS, Patrick John. Continuo realization in Handel's vocal music. Ann Arbor, Mich.: UMI Research Press, c1989.

SPENCER. Robert. Chitarrone, Theorbo and Archlute. Early Music. Vol. 4 (October 1976), pp. 407-422. 